\title{
THE MINIMALLY INVASIVE BIPOLAR TECHNIQUE FOR THE TREATMENT OF SPINAL DEFORMITIES IN CHILDREN AND ADOLESCENTS
}

\author{
TÉCNICA BIPOLAR MINIMAMENTE INVASIVA PARA O TRATAMENTO DE DEFORMIDADES \\ DA COLUNA VERTEBRAL EM CRIANÇAS E ADOLESCENTES
}

TÉCNICA BIPOLAR MÍNIMAMENTE INVASIVA PARA EL TRATAMIENTO DE DEFORMIDADES

DE LA COLUMNA VERTEBRAL EN NIÑOS Y ADOLESCENTES

LOTFI MILADI

1. Necker Hospital, Pediatric Orthopedics Department, Paris, France.

\begin{abstract}
Scoliosis is a three-dimensional deformity of the spine that occurs during growth. Surgery is indicated when the curve progresses despite conservative treatment. The traditional surgical treatment involves correction of the deformity using segmental spinal fixation to obtain solid bone fusion by decortication and bone grafting. Vertebral osteotomies or even vertebrectomies may be required for huge deformities. These techniques provide good results, but they are invasive, involving lengthy surgery, increased blood loss, and longer recovery times. Therefore, we developed another technique: The Minimally Invasive Bipolar Technique, based on gradual internal correction of the deformity secondary to viscoelastic relaxation of the trunk. This method is aimed at reducing surgical risks while providing satisfactory results and improving quality of life for the patients and their families. Additionally, this technique is cost effective for public health. Type of the study: Update article.
\end{abstract}

Keywords: Minimally Invasive Surgery, Scoliosis, Neuromuscular Diseases, Deformity.

\section{RESUMO}

A escoliose é uma deformidade tridimensional da coluna vertebral, que ocorre durante o crescimento. A cirurgia é indicada quando a curva progride apesar do tratamento conservador. O tratamento cirúrgico tradicional envolve a correção da deformidade usando a fixação espinhal segmentar para obter fusão óssea sólida por decorticação e enxerto ósseo. As osteotomias vertebrais ou mesmo vertebrectomias podem ser necessárias nas grandes deformidades. Essas técnicas fornecem bons resultados, mas são invasivas e envolvem maior tempo de cirurgia e maior perda de sangue, além da recuperação prolongada. Por isso, desenvolvemos outra técnica - a técnica bipolar minimamente invasiva -, baseada na correção interna gradual da deformidade secundária ao relaxamento viscoelástico do tronco. Este método visa reduzir os riscos cirúrgicos, proporcionando resultados satisfatórios e melhorando a qualidade de vida do paciente e de sua família. Além disso, essa técnica tem boa relação de custo-benefício para a saúde pública. Tipo de Estudo: Artigo de atualização.

Descritores: Procedimentos Cirúrgicos Minimamente Invasivos, Escoliose, Doenças Neuromusculares, Deformidade.

\section{RESUMEN}

La escoliosis es una deformidad tridimensional de la columna vertebral, que ocurre durante el crecimiento. La cirugía está indicada cuando la curva progresa a pesar del tratamiento conservador. El tratamiento quirúrgico tradicional abarca la corrección de la deformidad usando la fijación espinal segmentaria para obtener fusión ósea sólida mediante decorticación e injerto óseo. Las osteotomías vertebrales o incluso las vertebrectomías pueden ser necesarias en las grandes deformidades. Estas técnicas proveen buenos resultados, pero son invasivas, y abarcan mayor tiempo de cirugía y mayor pérdida de sangre, además de la recuperación prolongada. Por eso, desarrollamos otra técnica - la técnica bipolar mínimamente invasiva -, basada en la corrección interna gradual de la deformidad secundaria a la relajación viscoelástica del tronco. Este método tiene como objetivo reducir los riesgos quirúrgicos, proporcionando resultados satisfactorios y mejorando la calidad de vida del paciente y su familia. Además, esta técnica tiene buena relación de costo-beneficio para la salud pública. Tipo de estudio: Artículo de actualización.

Descriptores: Procedimientos Quirúrgicos Minimante Invasivos, Escoliosis, Enfermidades Neuromusculares, Deformidad.

\section{INTRODUCTION}

Whatever the etiology, some forms of early onset scoliosis in young children are progressive and resistant to conservative treatment, requiring surgery. Surgery is also indicated in cases of neglected and complex spinal deformities in adolescents and young adults.

Surgical treatment for scoliosis has evolved considerably in the past thirty years, since the advent of CD instrumentation in the 
early 1980s. Spinal osteosynthesis has undergone a major leap, with sophisticated implants and efficient ancillaries, enabling solid vertebral fixations to be performed, with excellent correction of spinal deformities in the three planes of space.

Nowadays, posterior vertebral arthrodesis is the "Gold Standard" technique; increasingly, surgeons are instrumenting all the fused levels with pedicle screws. ${ }^{1}$

For severe and rigid curves, anterior release, vertebral osteotomies, or even vertebrectomies may be indicated in order to obtain maximum mobility and the best possible immediate correction of the deformity, since vertebral arthrodesis is a final operation.

The increase in implant density and the invasiveness of the osteotomies may result in higher surgical risks, particularly hemorrhagic and neurological ones. ${ }^{2-6}$

In contrast to these risky methods, and in order to reduce the surgical risks for complex spinal deformities, we use now the minimally invasive bipolar technique, which involves progressive spinal detorsion secondary to gradual viscoelastic relaxation of the soft tissues of the trunk under constant tension.

\section{METHODS}

Viscoelasticity is the property of a substance exhibiting both elastic and viscous behavior, the application of stress causing temporary deformation if the stress is quickly removed but permanent deformation if it is maintained (Oxford dictionary definition).

On a simple traction test, plastic deformity produces an irreversible elongation of the body. On the stress-strain graph, the elastic part corresponds to the linear part of the curve (reversible elongation), the plastic domain corresponds to the bended part of this curve (permanent deformation). The limit between the two domains defines the elasticity limit, noted here "EL". (Figure 1)

Based on this viscoelastic behavior, the progressive relaxation of soft tissues and bone under permanent traction results in a gradual detorsion of the spinal deformity.

The bipolar method consists of performing a telescopic construct, bridging the curve and maintaining a constant tension between the two extremities. (Figure 2)

However, to successfully obtain progressive bipolar detorsion four conditions are required:

- A strong and stable bipolar fixation

- A solid link between the fixation points

- The preservation of the intermediate zone

- Maintaining a constant tension between the two ends of the construct

\section{Strong and stable bipolar fixation}

The bipolar method requires a solid and stable fixation to be achieved at each end of the construct, which must be able to resist long-term, until progressive stiffening of the spine.

It is therefore a rigorous technique requiring an experienced surgeon, due to the absence of intermediate anchors in the construct and the absence of bone grafting.

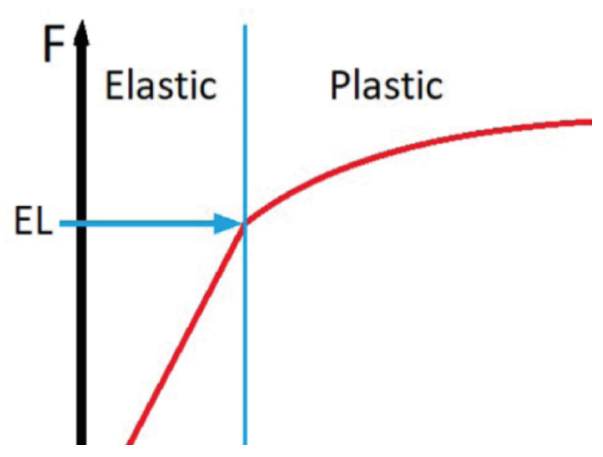

Figure 1. Graph showing the curve of viscoelastic deformation produced by the stress over time.

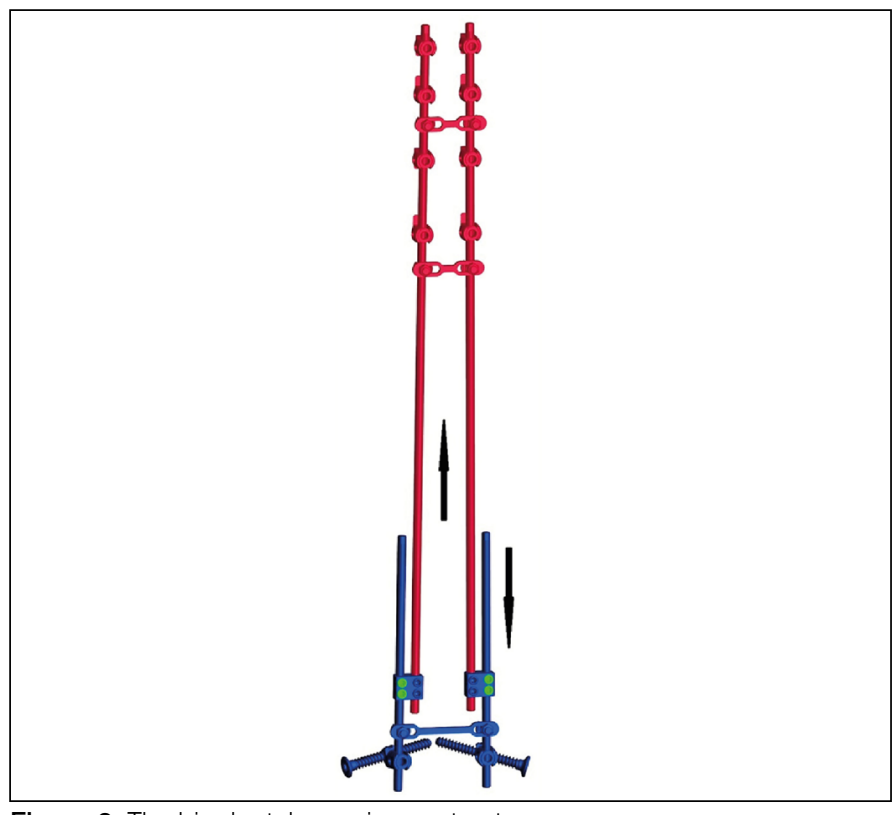

Figure 2. The bipolar telescopic construct.

\section{Proximal fixation}

Proximal fixation is performed with two supra-laminar pedicle hook claws on each side of four or five adjacent vertebrae, to ensure good stability and excellent pullout resistance, thanks to the "claw effect" of the hooks, which are positioned in the opposite direction to the compression? ${ }^{7}$. (Figure 3)

The hook claws grip the posterior vertebral arch.

We insert the hooks without preparation to preserve all the bone capital and to ensure a solid fixation. (Figure 4)

In our experience, proximal anchors with hook claws reduce the risk of implant dislodgement and proximal junctional kyphosis, especially in long constructs, even in hyper kyphotic deformities..$^{8,9}$

\section{Distal fixation}

In idiopathic and syndromic scoliosis, distal fixation is performed using pedicle screws in two or three levels on each side. (Figure 5)

In neuromuscular scoliosis, pelvic fixation is performed using iliosacral screws, which provide great stability and high resistance to dislodgement.

Iliosacral screws have a full bony path, from the iliac ala to the S1 body, crossing three or even four cortices. Their position is perpendicular to the rods into which they are fixed, at the middle of the rods, by locked connectors. The bilateral iliosacral screws realize with the crosslink a triangular construct that represents a very resistant fixation against pullout forces, even in very fragile bone. ${ }^{8,9}$ (Figure 6)

\section{A solid link between fixation points}

The anchors at two ends of the construct must be connected by a solid link, with one or two rods of $5.5 \mathrm{~mm}$ in diameter or greater, even in young children, in order to reduce the risk of rod breakage.

This link between the two poles of the construct is constructed using two pre-bent telescopic rods on each side: a long medial rod fixed to the hooks at the top, and a short lateral rod fixed to the pedicle screws or iliosacral connector at the bottom. The two rods are connected to each other by closed dominoes.

For patients with high body weight (more than $40 \mathrm{~kg}$ ), we recommend, additionally, using cobalt chromium rods fixed to the pelvis, to reduce the risk of breakage, especially in walking and hypertonic neuromuscular patients. A four-rod construct may also be performed in dynamic patients with cobalt chromium rods fixed until the pelvis. (Figure 7) We recommend this construct for adult cases too.

In all cases, the construct must be reinforced by two proximal crosslinks in a thoraco-lumbar construct, and at least three 


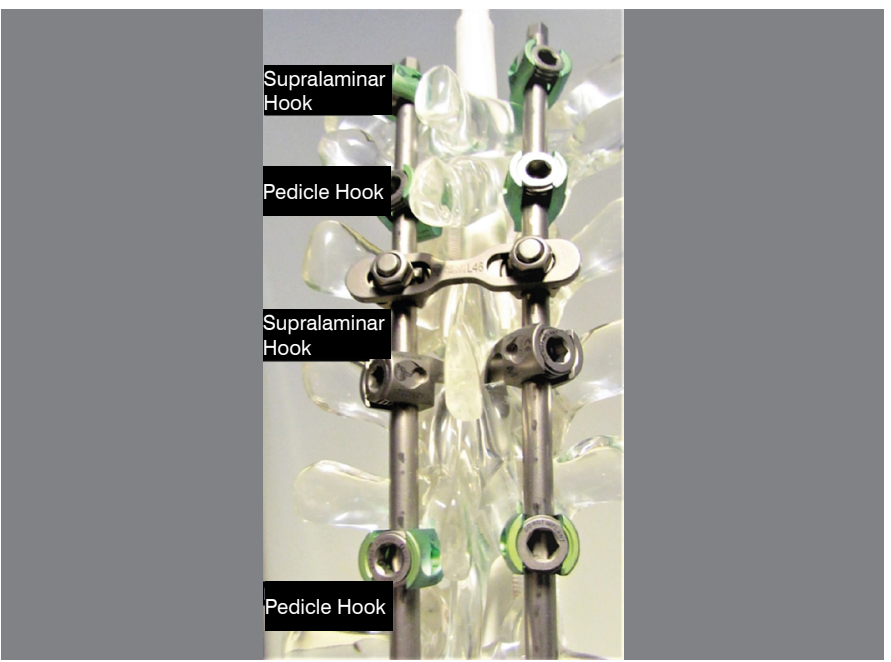

Figure 3. The proximal fixation with hook claws.

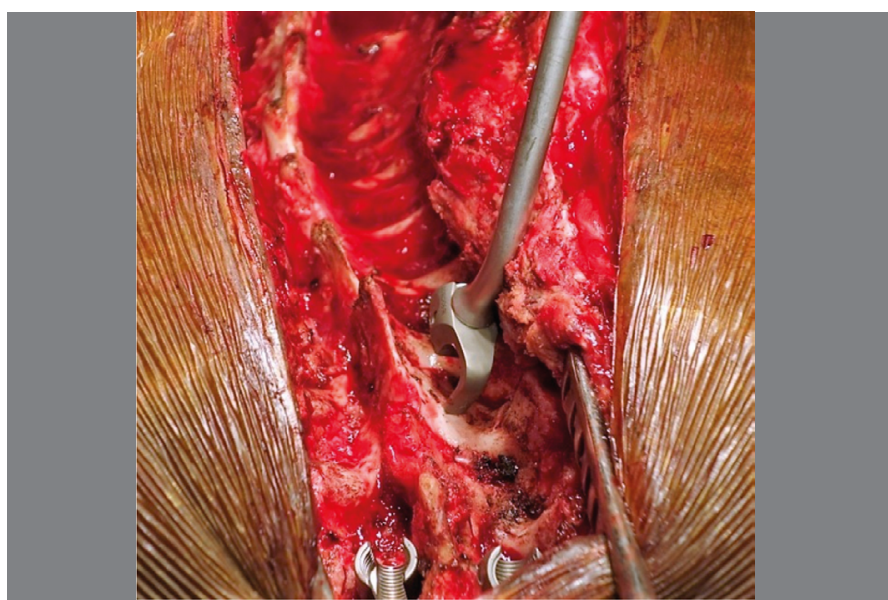

Figure 4. Insertion of the hook without preparation.

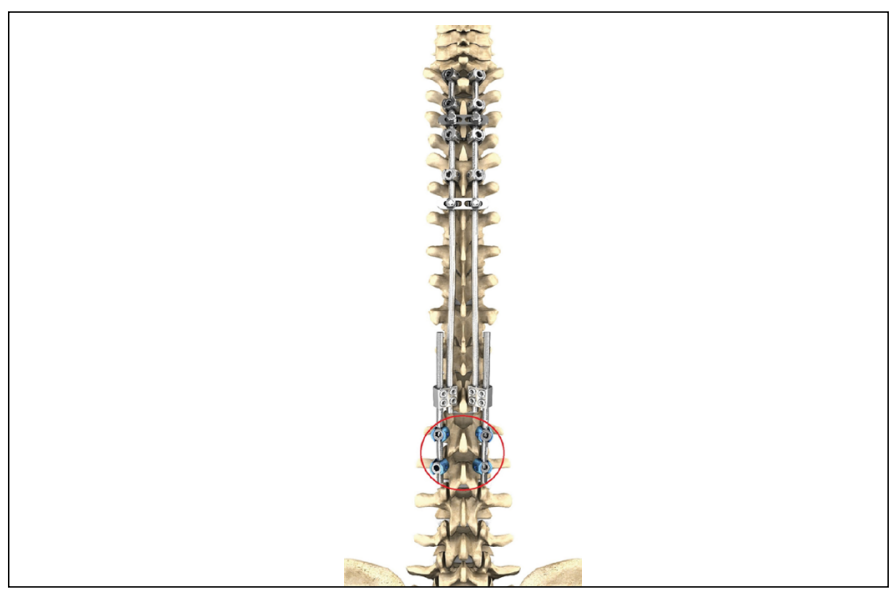

Figure 5. Bipolar construct with lumbar distal fixation.

crosslinks, two proximal and one distal, very close to the iliosacral connectors, in a thoraco-sacral construct as shown in Figure 2.

The bipolar construct, performed in this way, is solid and stable enough to avoid the need to wear a cast or brace postoperatively.

\section{Intermediate zone preservation}

It is important to use a minimally invasive approach, through two small incisions in front of the fixation zones of the spine, avoiding working in the intermediate zone which must remain free of any implant. That helps to preserve the spinal and thoracic growth of

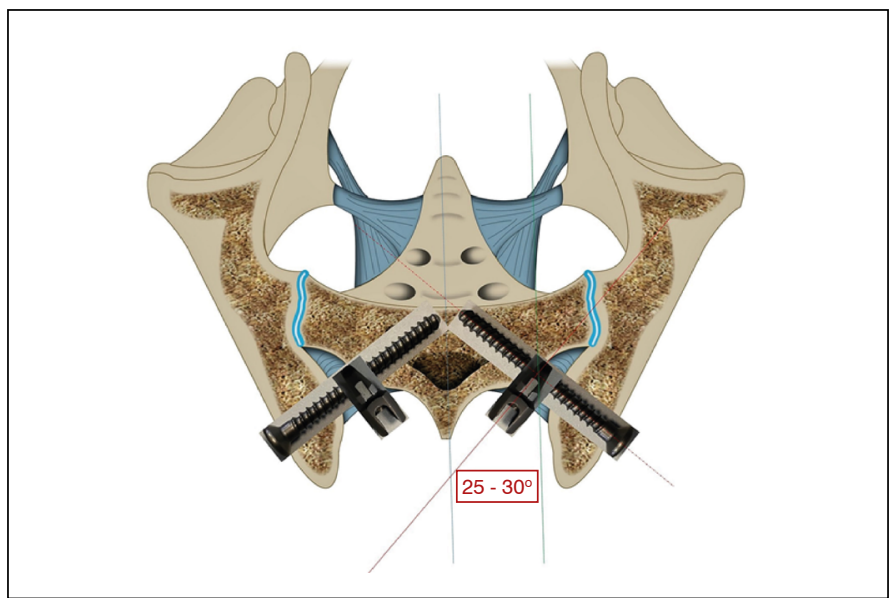

Figure 6. Triangular shape of pelvic fixation with iliosacral screws.

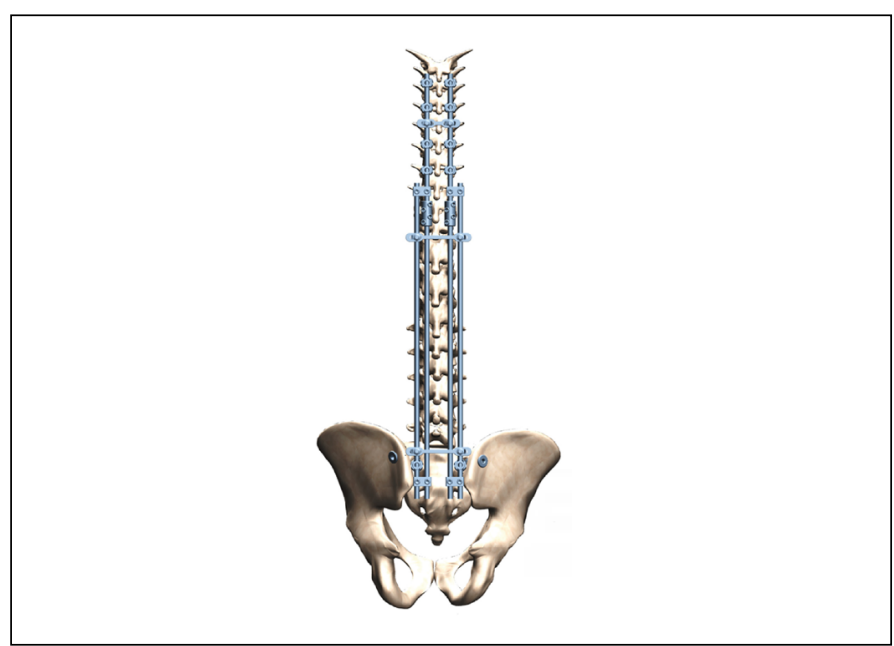

Figure 7. Four-rod bipolar construct.

the immature child, thanks to the reduction of fibrosis and spontaneous fusion risks, particularly if there is a need for repeated rod lengthening surgeries.

It is necessary to maintain the flexibility of this area, which is generally the site of maximum spinal deformity, in order to continue progressive correction by repeated rod lengthening procedures.

\section{Maintaining constant tension inside the construct}

Correction of spinal deformities by the bipolar method in the frontal plane is obtained with a moderate distraction applied in the initial surgery and during future surgeries, with more or less symmetrical rod lengthening, as required. (Figures $8 \mathrm{~A}, \mathrm{~B}, \mathrm{C}, \mathrm{D}, \mathrm{E}, \mathrm{F}, \mathrm{G}, \mathrm{H}, \mathrm{I}, \mathrm{J}$ )

In the sagittal plane, correction is obtained by bending the rods prior to their insertion and maneuvering them into the implants, with additional in situ bending if needed. For hyper-kyphotic deformities, the length of the construct provides a powerful lever arm, allowing easy correction of the kyphosis even when they are stiff and angular. (Figures 9A, B, C, D, E, F, G, H)

However, repeated rod-lengthening procedures represent the main drawback of the method. For this reason, we now use the One-Way Self-Expanding Rod, which can be expanded spontaneously or by external axial traction maneuvers. (Figure 10)

For severe and rigid spinal deformities, we strongly recommend preparing the patients 3 to 6 weeks prior to surgery, with progressive halo-gravity traction. This preoperative correction enables a better curve correction and decreases the risk of neurological complications in severe spinal deformities. We also operate on patients under moderate intraoperative traction and under control of somesthetic and motor evoked potentials. 


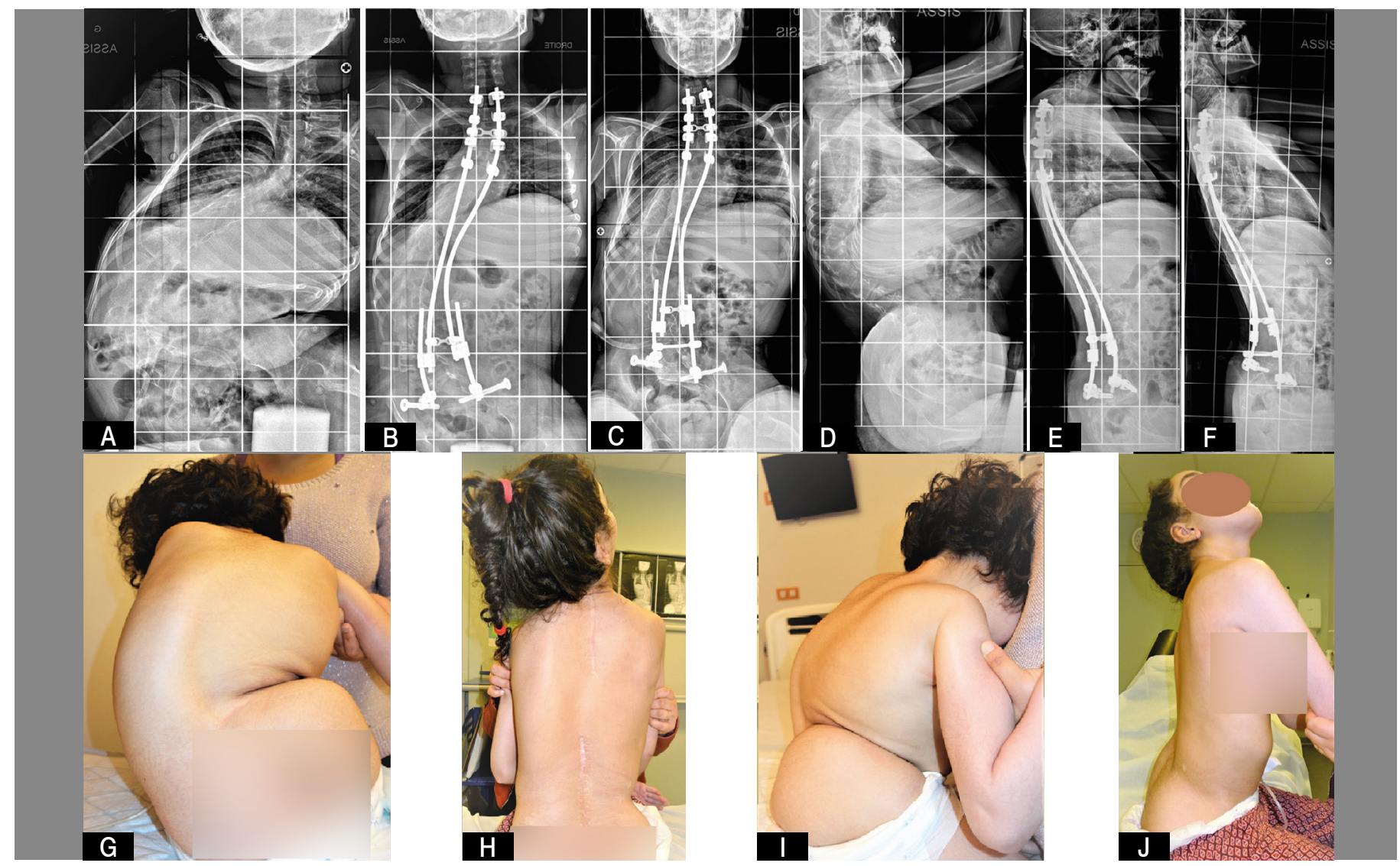

Figure 8. Case of neuromuscular scoliosis 10 years old. (A) Preoperative AP X-Ray, (B) Postoperative, (C) Post asymmetric rod lengthening 2 years after initial surgery with complete correction of residual pelvic obliquity, (D, E and F) lateral X-Rays, ( $G$ and I) pre and postoperative posterior views, ( $H$ and J) pre and postoperative lateral views.

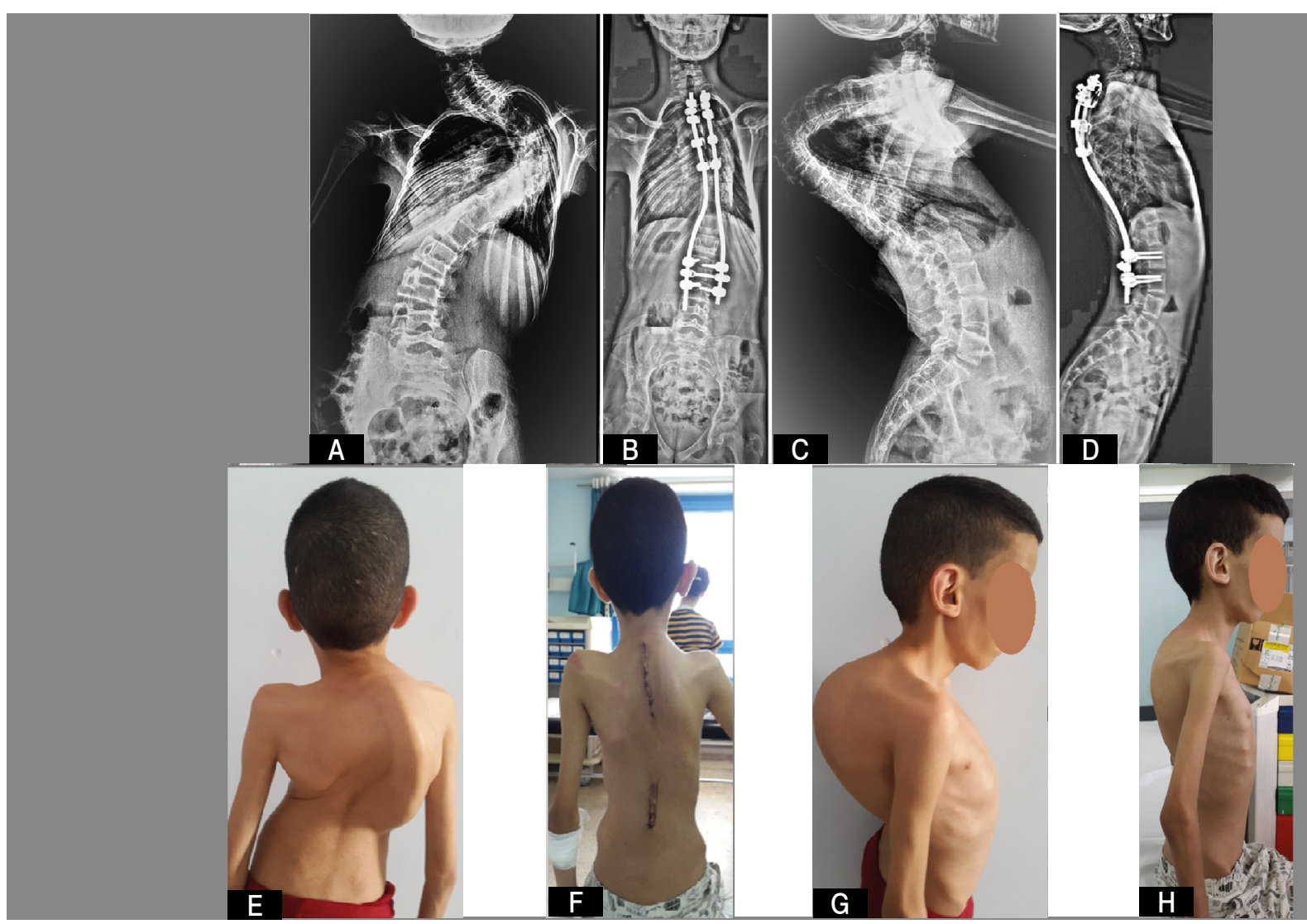

Figure 9. Case of neglected infantile scoliosis 14 years old operated after 4 weeks halo-traction. (A) Preoperative AP X-Ray, (B) Postoperative, (C) Preoperative lateral X-Ray, (D) Postoperative, (E and F) pre and postoperative posterior views, ( $G$ and $H)$ lateral views. 

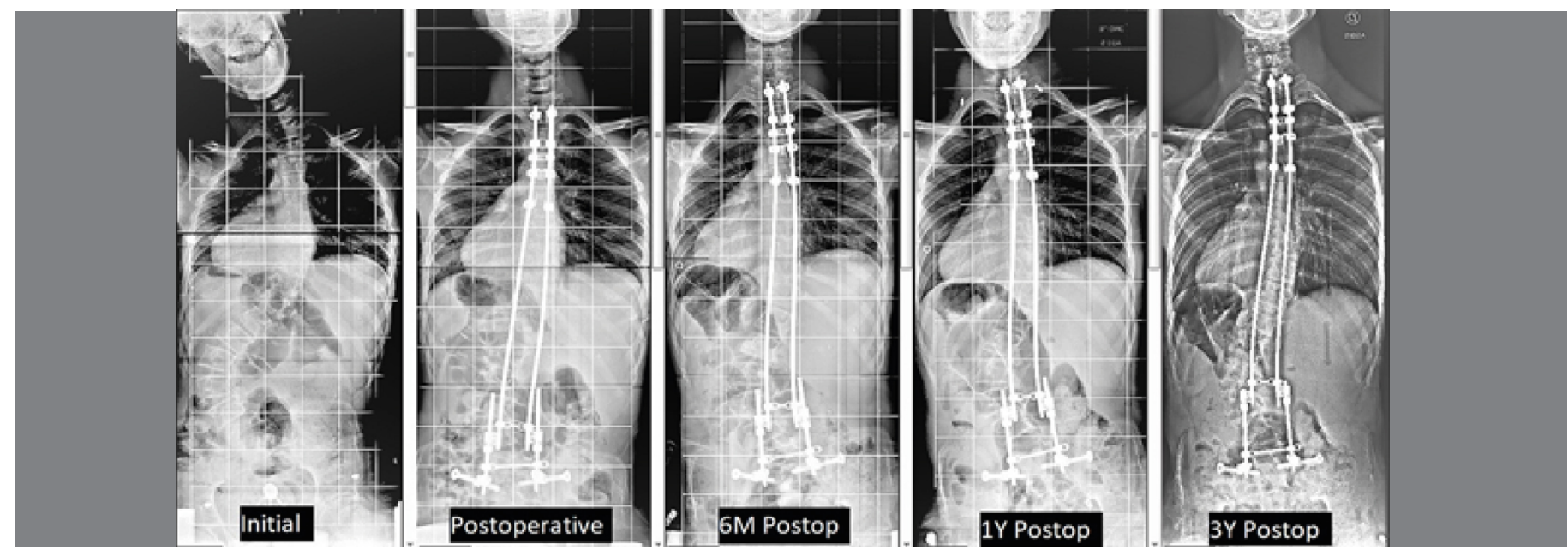

Figure 10. Consecutive X-Rays of a neuromuscular scoliosis case in a 17-year-old operated with self-expanding rods, showing spontaneous expansion of the device over time.

\section{DISCUSSION}

The traditional techniques provide vertebral derotation and translation by a full segmental instrumentation, leading to an immediate and definitive correction of the deformity. However, these methods may expose the patient to neurological and hemorrhagic risks. ${ }^{10,11}$ The minimally invasive bipolar technique achieves global and progressive detorsion of the whole spine, leading to recovery of its initial shape secondary to the correction of the trunk collapse, due to the constant tension maintained by the rods between the two ends of the construct. The anti-collapse method is not new; it is none other than the axial traction method that was used to correct spinal deformities in the middle age by different authors. ${ }^{12}$

In 1863, Lewis A. Sayre introduced a combined method associating traction with a plaster of Paris cast, known as a Sayre jacket, to treat scoliosis. ${ }^{13}$ (Figure 11)

In the bipolar concept, the rods fixed at the two distant ends of the construct with tension act in the same way as the plaster cast, to maintain the correction.

This progressive method enables a good correction to be obtained, thanks to the time factor. Indeed, by fixing all levels and especially the apex of the deformity associated with bone fusion, arthrodesis does not permit a secondary improvement of the residual deformity, unlike to the bipolar method.

However, the bipolar method is a rigorous technique that requires a learning curve, especially in the use of thoracic hooks.

Furthermore, for distal fixation, although the use of pedicle screws and iliac extension screws is familiar to most spine surgeons, pelvic fixation by iliosacral screws requires a steep learning curve and attention to some fixation rules, even if a dedicated ancillary has been developed. Intraoperative navigation may also be used. The iliosacral technique is very solid and stable, even in the most deformed and fragile bones. ${ }^{8,9}$

This concept of progressive detorsion by the minimally invasive bipolar technique can be applied whatever the patient's age. It enables good correction of spinal deformities, even severe and rigid ones, with a high level of security, unlike the more aggressive techniques that achieve immediate correction but with major risks when osteotomies or vertebrectomies are performed.

The strength of the construct and its resistance over time also enabled us to avoid the final arthrodesis initially planned for the first patients operated by this technique. Indeed, we observed a progressive and delayed stiffening of the spine in the oldest cases, induced by the presence of metallic rods implanted several years ago. ${ }^{14,15}$

Finally, performing this technique early on, in an immature child, provides undeniable comfort to the patient as well as dispensing with the need for a brace. It reduces the overall cost of treatment for the public health service, thanks to the reduced number of implants, the low rate of complications and shorter hospital stays, especially in the ICU, when compared to the traditional techniques.

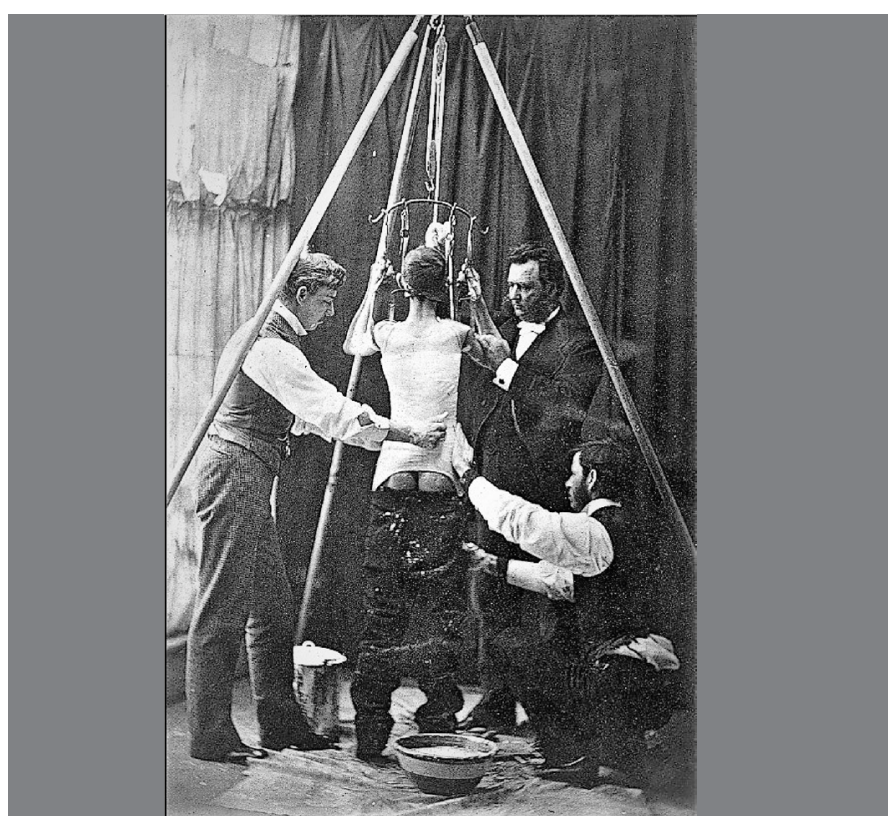

Figure 11. Lewis A. Sayre creating a plaster cast Jacket under traction to treat scoliosis

\section{CONCLUSION}

Since neuromuscular surgery and complex surgery for spinal deformities is mainly functional, it must aim to preserve growth and respiratory function in children, rebalance the trunk, and avoid arthrosis in adulthood. It is therefore important to weigh the risks and benefits for the patient, especially in the case of more severe deformities, and the most fragile patients.

The technique of progressive detorsion seems to meet the main objectives of the surgical treatment of neuromuscular and complex spinal deformities, with significantly lower risks than traditional arthrodesis methods.

The bipolar technique could be a good alternative to arthrodesis, and should be proposed earlier as it preserves growth. But it is a rigorous technique, requiring a steep learning curve and adherence to some rules.

The author declare no potential conflict of interest related to this article. 


\section{REFERENCES}

1. Suk SI, Lee CK, Kim WJ, Chung YJ, Park YB. Segmental pedicle screw fixation in the treatment of thoracic idiopathic scoliosis. Spine (Phila Pa 1976). 1995;20(12):1399-405.

2. Suk SI, Kim JH, Kim WJ, Lee SM, Chung ER, Nah JH. Posterior vertebral column resection for severe spinal deformities. Spine (Phila Pa 1976). 2002;27(21):2374-82

3. Suk SI, Chung ER, Kim JH, Kim SS, Lee JS, Choi WK. Posterior vertebral column resection for severe rigid scoliosis. Spine (Phila Pa 1976). 2005;30(14):1682-7.

4. Lenke LG, Sides BA, Koester LA, Hensley M, Blanke KM. Vertebral column resection for the treatment of severe spinal deformity. Clin Orthop Relat Res. 2010;468(3):687-99.

5. Lenke LG, O'Leary PT, Bridwell KH, Sides BA, Koester LA, Blanke KM. Posterior vertebral column resection for severe pediatric deformity: minimum two-year follow-up of thirty-five consecutive patients. Spine (Phila Pa 1976) 2009;34(20):2213-21.

6. Lenke LG, Newton PO, Sucato DJ, Shufflebarger HL, Emans JB, Sponseller PD, et al. Complications after 147 consecutive vertebral column resections for severe pediatric spinal deformity: a multicenter analysis. Spine (Phila Pa 1976). 2013;38(2):119-32.

7. Gaume M, Persohn S, Vergari C, Glorion C, Skalli W, Miladi L. Biomechanical cadaver study of proximal fixation in a minimally invasive bipolar construct. Spine Deform. 2020;8(1):33-8.

8. Miladi LT, Ghanem IB, Draoui MM, Zeller RD, Dubousset JF. lliosacral screw fixation for pelvic obliquity in neuromuscular scoliosis. A long-term follow-up study. Spine (Phila Pa 1976). 1997;22(15):1722-9
9. Miladi L, Gaume M, Khouri N, Johnson M, Topouchian V, Glorion C. Minimally invasive surgery for neuromuscular scoliosis. Results and complications in a series of one hundred patients. Spine (Phila Pa 1976). 2018;43(16):968-75.

10. Reames DL, Smith JS, Fu KMG, Polly Jr DW, Ames CP, Berven SH, et al. Complications in the surgical treatment of 19,360 cases of pediatric scoliosis. A review of the scoliosis research society morbidity and mortality database. Spine (Phila Pa 1976). 2011;36(18):1484-91.

11. Pugely AJ, Martin CT, Gao Y, Ilgenfritz R, Weinstein $S$. The incidence and risk factors for short-term morbidity and mortality in pediatric deformity spinal surgery. Spine (Phila Pa 1976). 2014;39(15):1225-34.

12. Redard P. Traité pratique des déviations de la colonne vertébrale. Paris: Masson Editeur; 1900.

13. Sayre LA. The history of the treatment of spondylitis and scoliosis by partial suspension and retention by means of plaster of Paris bandages. New York: D. Appleton \& Co; 1895.

14. Jain A, Sponseller PD, Flynn JM, Shah SA, Thompson GH, Emans JB, et al. Avoidance of "final" surgical fusion after growing-rod treatment for early-onset scoliosis. $J$ Bone Joint Surg Am. 2016;98(13):1073-8.

15. Bouthors C, Gaume M, Glorion C, Miladi L. Outcomes at skeletal maturity of 34 children with scoliosis treated with a traditional single growing rod. Spine J. 2019;44(23):1630-7. 